\title{
Pierogi z fiżonem. Praktyki jedzeniowe i tożsamość Brazylijczyków polskiego pochodzenia w południowobrazylijskiej wsi
}

Streszczenie: Celem tego artykułu jest analiza codziennych i świątecznych praktyk jedzeniowych potomków imigrantów polskich w Brazylii w kontekście ich tożsamości zbiorowych i indywidualnych. Badania były prowadzone metodą obserwacji uczestniczącej, autorka prowadziła również wywiady formalne i nieformalne, a także obserwowała aktywność Brazylijczyków polskiego pochodzenia w internecie (Facebook, blogosfera). Autorka skupia uwagę przede wszystkim na jednym produkcie: pierogach, które są uważane za „typowe jedzenie” potomków Polaków. Pokazuje, jak pierogi, jako danie łatwe do przygotowania, pożywne i tanie, są reprodukowane w społeczności polonijnej w przestrzeni domowej i publicznej, stając się częścią programu kulturowego diaspory podczas różnego rodzaju świąt i festiwali.

Argumentuje, że pierogi, podobnie jak inne produkty uważane za „typowe”, są podatne na patrymonializację, ponieważ stoją w centrum tożsamości diaspory. Jednocześnie proponuje wyjście poza perspektywę etniczną i narodową i pokazanie, że zwyczaje jedzeniowe stanowią element tożsamości wiejskiej, środkowo-europejskiej, wspólnej z potomkami Ukraińców czy emigrantów z Pomorza Zachodniego, związanej z podobnym trybem życia i sposobem gospodarowania.

Słowa kluczowe: diaspora, Brazylia, praktyki jedzeniowe, tożsamość, lokalność

\section{Dumplings with Beans. Food Practices and Identity of Brazilians of Polish Origin in the South-Brazilian Village}

The purpose of this article is to analyze the daily and festive food practices of descendants of Polish immigrants in Brazil in the context of their collective and individual identities. The research was conducted by the participant observation method, the author also conducted

\footnotetext{
${ }^{1}$ Kontakt: k.bielenin@uw.edu.pl
} 
formal and informal interviews, and also observed the activity of Brazilians of Polish origin on the Internet (Facebook, blogosphere). The author focuses primarily on one product: dumplings, which are considered "typical food" for descendants of Poles. She shows how dumplings, as an easy-to-prepare, nutritious and cheap dish, are reproduced in the Polish community in the public and private spaces, becoming part of the cultural diaspora program during various festivals.

It argues that dumplings, like other products considered „typical”, are susceptible to patrimonialization because they are at the center of the identity of the diaspora. At the same time, it proposes to move beyond the ethnic and national perspectives and show that eating habits are part of the rural, central-European identity, shared with the descendants of Ukrainians and emigrants from Western Pomerania, related to a similar way of life and modes of farming.

Keywords: diaspora, Brazil, food practices, identity, locality

„Specjalność polskiej kuchni.

Jakie są, każdy wie - farsz zawinięty w okrągłe (ale także prostokątne) płatki cienkiego ciasta, ale nikt chyba nie jadł wszystkich rodzajów pierogów, tak wiele ich się gotowało (...) i gotuje" (Kozioł 2003: 196).

\section{Wprowadzenie}

„Nadziane wspomnieniami” - tak określa pierogi historyczka Neli Maria Teleginski, potomkini Polaków w południowej Brazylii. Pisze, że pierogi są jedną z najbardziej popularnych potraw w Polsce, i są uważane niemal za symbol narodowy. W Brazylii zaś przywołują wspomnienia o imigranckiej przeszłości (Teleginski 2014).

Punktem wyjścia do tego artykułu czynię rozważania o pierogach właśnie o potrawie znanej i uznawanej za typową, charakterystyczną dla społeczności polonijnej w Brazylii, a także popularnej w dawnej i współczesnej Polsce. Próbuję sobie zadać pytanie, jak potomkowie Polaków praktykują swoją tożsamość na co dzień i przekazują z pokolenia na pokolenie. A także, co definiuje tę tożsamość: imigranckie pochodzenie, narodowość, religia, język, obecne miejsce zamieszkania? Skupię się na praktykach jedzeniowych, a zwłaszcza na przygotowywaniu, konsumowaniu i reprezentowaniu pierogów: tym, co jest jadane na co dzień i od święta oraz co uważane jest za jedzenie „polskie” czy „typowe” dla Brazylijczyków polskiego pochodzenia. Jak pierogi wpisują się w codzienne i świąteczne zwyczaje jedzeniowe Brazylijczyków polskiego pochodzenia, jak funkcjonują w przestrzeni publicznej: restauracjach, sklepach, podczas festiwali i świąt organizowanych przez społeczność polonijną i dla niej, a także jak wiążą się z przeszłością migracyjną i tożsamościami indywidualnymi i zbiorowymi. Zastanawiam się również, jak to jest „być Polakiem” w południowej Brazylii. Wreszcie, dlaczego pierogi jadają w Brazylii również Ukraińcy i dlaczego także oni uważają, że jest to ich comida típica? Zapewne nie uda mi się na te wszystkie pytania w niniejszym tekście 
wyczerpująco odpowiedzieć. Wymagają one bowiem dalszych pogłębionych studiów na ten temat. Spróbuję przede wszystkim oddać głos potomkom polskich chłopów, którzy nadal żyją na wsi i zajmują się pracą na roli, a których dziedzictwo rzadko wpisuje się w debatę dotyczącą Polonii.

Wnioski opieram na wynikach badań etnograficznych, które prowadziłam w stanie Santa Catarina i Paraná w Brazylii w 2015 i 2016 roku na badaniach pilotażowych z przełomu 2011 i 2012 r., a także na badaniach netnograficznych (Kozinets 2012): regularnej obserwacji kilku stron na Facebooku (Descendentes de Poloneses no Brasil; Culinária Polonesa (Brasil) i Poloneses no Brasil) oraz wybranych stron profilowych moich rozmówców.

\section{Pierogi w polskiej tradycji i kulturze}

Na początek należy odpowiedzieć na pytanie, dlaczego właśnie pierogi są tak popularne wśród Polaków w Polsce i ich potomków za granicą, jaka jest ich historia i o jakich pierogach w ogóle będzie mowa.

Słowniki języka polskiego rozróżniają przede wszystkim dwie formy: w liczbie pojedynczej pieróg (np. Inny słownik języka polskiego [ISJP], t. 2: „Pieróg to potrawa $\mathrm{z}$ kruchego lub drożdżowego ciasta $\mathrm{z}$ farszem z mięsa lub z kapusty, grzybów itp.”) oraz mnogiej: pierogi (ISJP, t. 2: „Pierogi to potrawa $z$ ciasta rozwałkowanego w cienkie krążki, w które zawinięto farsz mięsny, grzybowy itp. i które charakterystycznie sklejono. Pierogi gotuje się w wodzie. Przyrządziła pierogi z mięsem... pierogi z jagodami... pierogi z serem. Ruskie pierogi to pierogi nadziane farszem z mielonych ziemniaków i twarogu"). To samo rozróżnienie pojawia się w książkach kucharskich i leksykonach kulinarnych.

Pierogi są potrawą łatwą do przyrządzenia (choć czasochłonną), tanią i pożywną. Rozmaite sposoby przygotowywania i podawania pierogów, a także sama łatwość ich sporządzania powodują, że po pierwsze, stają się one emblematami (Maciel 2004) różnych grup narodowych i etnicznych, a po drugie są podatne na zmianę: adaptacje, przekształcenia i zapożyczenia.

Źródła podają, że w na terenach Słowiańszczyzny różne rodzaje pierogów są znane od co najmniej kilkuset lat (Lechowski 2013: 253; Lemnis, Vitry 1979: 36). Swoją sławę zawdzięczają legendzie o świętym Jacku², który w czasie wojny karmił nimi głodującą ludność. W XIX-wiecznych i wczesnych XX-wiecznych książkach

${ }^{2}$ Legenda mówi, że św. Jacek Odrowąż był autorem pieczonych pierogów z mąki razowej z farszem z twarogu i dziko rosnących pieczarek. Święty Jacek, jadąc na Ruś Kijowską, miał zatrzymać się w podkarpackiej miejscowości o nazwie Nockowa i przekazać ludziom recepturę. Od tamtej pory miejscowi robili pierogi św. Jacka na wielkie święto lub w niedzielę. Odmawiano wtedy również modlitwę: „Święty Jacku z pierogami, módl się do Boga za nami, żeby te pierogi cały rok na stole były i nas od głodu broniły”. Od 2010 roku „pieczone pierogi św. Jacka” wpisane są na „Listę produktów tradycyjnych" (Leksykon... 2012: 108). 
kucharskich są uważane za typowe danie postne, choć autorki podają również przepisy na pierogi z mięsem. Popularna w pierwszych dekadach XX wieku Marya Ochorowicz-Monatowa, autorka Uniwersalnej książki kucharskiej, w rozdziale o daniach mącznych podaje aż 16 różnych rodzajów pierogów i pierożków: gotowanych i smażonych, $z$ różnym rodzajem farszu i z różnych rodzajów mąki (pszennej, razowej, gryczanej). Proponuje następujący przepis na ciasto, wydaje się, że nadal powszechny: „Zagnieść ciasto jak na kluski z jednem całem jajem, dodając wody letniej tyle, ile mąka przyjmie i rozwałkować cienko. Potem układać przy brzegu małe kupki farszu, przykryć ciastem, wycinać foremką blaszaną lub zwykłym kieliszkiem, a brzegi każdego pierożka silnie w palcach zlepiać, aby w gotowaniu się nie rozkleiły. (...) Mniej wprawne kucharki wycinają z ciasta kieliszkiem lub szklaneczką okrągłe placuszki, nakładają do każdego w środek farszu i złożywszy we dwoje brzegi ze sobą zlepiają. Po zrobieniu należy pierogi układać na sicie jeden obok drugiego, gotować tak samo jak kluski. Po wrzuceniu na gotującą osoloną wodę, przykryć pokrywką, a po paru minutach, gdy wypłyną na wierzch, wyjmować łyżką druszlakową na półmisek i polać masłem" (Ochorowicz-Monatowa 1913: 569). Równie popularna autorka wcześniejsza, Lucyna Ćwierczakiewiczowa, stosuje określenie „pierogi ruskie” na te z rozmaitym farszem: mięsem, kapustą słodką i kiszoną, rybą, a nawet ryżem (Ćwierczakiewiczowa 1871: 131-134). Co ważne, pierogi pojawiały się na stołach osób z różnych warstw społecznych. Była to potrawa zarówno chłopów, jak i mieszczaństwa czy szlachty. Wynika to zapewne $\mathrm{z}$ tego, $\mathrm{w}$ jak różnorodny sposób można je przygotować, $\mathrm{z}$ jak rozmaitymi nadzieniami, a także z tego, że często w kuchniach pracowały służące pochodzące ze wsi.

Rozmaitość rodzajów pierogów, używanego ciasta, a także farszów pokazuje, że danie to może być łatwo adaptowane do przyzwyczajeń smakowych i różnic regionalnych. Na przykład w „Gazecie Polskiej w Brazylii” w 1938 roku ukazał się przepis na „pierożki z pomarańczą”: „Pół kila mąki wsypać na stolnicę, zrobić w środku dołek, wbić trzy żółtka, 4 łyżki śmietany, zagnieść ciasto, rozwałkować cieniutko, wykrawać szklanką krążki. Na każdy krążek położyć ćwiartkę pomarańczy (pestki o ile się da i białe włókna usunąć), brzegi zacisnąć, ugotować jak każde pierożki. Jeżeli je podajemy na gorąco, wodę lekko osolić i po wyjęciu na półmisek natychmiast, żeby się nie kleiły oblać masłem z bułeczką. Jeżeli podajemy na zimno, wody do gotowania prawie nie solić, po wyjęciu przelać obficie zimną wodą. Osobno podać cukier i śmietanę" (Gazeta... 1938: 9).

\section{Inspiracje teoretyczne: migracja i jedzenie}

Tematyka jedzenia i migracji jest szeroko poruszana w naukach społecznych od co najmniej dwóch dekad. Zazwyczaj jednak pisze się o powiązaniach transnarodowych i bezpośrednich więziach migrantów z krajem pochodzenia (Abbots 
2016), w tym przede wszystkim o zmieniających się praktykach jedzeniowych pod wpływem migracji (Diner 2001; Wandel i in. 2008; Mata-Codesal, Abranches 2018): o tym, w jaki sposób migranci przywożą ze sobą „własne” produkty z kraju pochodzenia (Kershen 2002), ale także jak uczą się nowych potraw i smaków (Bielenin-Lenczowska 2018). Znacznie mniej jest badań, które koncentrują się na praktykach jedzeniowych kolejnych pokoleń migrantów, czyli diaspory (Mintz 2008; Kelly 2001), a mogą one wnieść wiele zarówno do studiów migracyjnych, jak i do studiów nad jedzeniem, ponieważ nie tylko pokazują, jak imigranci adaptują nowe smaki i produkty do swoich zwyczajów jedzeniowych, ale również w jaki sposób pewne produkty stają się elementem tożsamości i dziedzictwa diaspory.

W moich badaniach skupiam się na trzecim i czwartym pokoleniu migrantów z ziem polskich, którzy w znacznej mierze nie mają żadnych kontaktów ze współczesną Polską. Jednak ich tradycje kulinarne nie zanikają (Poulain 2013: 151), chociaż ma miejsce zarówno wprowadzanie nowych składników, jak i sposobów przygotowania potraw czy ich serwowania. Ponadto, dzięki mediom społecznościowym, zwłaszcza Facebookowi, potomkowie Polaków mają możliwość wymieniania się wiedzą i doświadczeniami związanymi z przygotowywaniem i spożywaniem posiłków.

W badaniach nad zwyczajami jedzeniowymi wspólnoty luterańskiej Amerykanów norweskiego pochodzenia Marie Tracie Kelly analizuje znaczenie dwóch potraw: lefse i lutefisk, tradycyjnych dla kraju pochodzenia emigrantów. Zauważa ona, że potrawy te jedzone i przygotowywane są nadal w kraju przyjmującym, podczas gdy w Norwegii zostały niemal zupełnie zapomniane. Można by podać przykłady tego typu potraw także w odniesieniu do Polaków w Brazylii, np. czarnina. Pierogi jednak jadane są i w Polsce, i poza nią. Co więcej, w Brazylii jest to również typowe danie potomków Ukraińców, a także potrawa znana Brazylijczykom niewschodnioeuropejskiego pochodzenia w stanie Paraná. Dlatego też istotnym wątkiem w poniższej analizie jest tożsamość. Emma-Jayne Abbots w swoim przeglądzie literatury na temat jedzenia i migracji zwraca uwagę na perspektywę etniczną i narodową, umieszczającą jedzenie migrantów w kontekście ich tożsamości i przynależności do kultury, z której się wywodzą. Zauważa, że jedzenie pełni istotną rolę w „zakotwiczeniu" ${ }^{3}$ migrantów w nowym miejscu oraz jest ważnym wyznacznikiem ich tożsamości etnicznej (Abbots 2016). Ja jednak chciałabym wyjść nieco poza tę perspektywę etniczną i narodową i pokazać, że praktyki jedzeniowe powiązane są z tożsamością lokalną migrantów: regionalną, wiejską, a także wykraczającą poza jedną grupę etniczną lub narodową. Sądzę, że pierogi są jadane, uważane za swoje, ponieważ stoją w centrum tożsamości diaspory - zarówno polskiej, jak i ukraińskiej.

3 Zob. koncepcję „społecznego zakotwiczenia” w: Grzymała-Kazłowska 2013. 


\section{Emigracja Polaków do Brazylii i ich osadnictwo w południowych stanach tego kraju}

Emigracja czy też osadnictwo z ziem polskich do Brazylii, związana jest z przemianami gospodarczymi i politycznymi zarówno w Europie, jak i w obu Amerykach w 2. połowie XIX wieku. Od połowy lat 80. do połowy lat 90. XIX w. trwał kryzys agrarny, związany z pojawieniem się taniego zboża ze Stanów Zjednoczonych i Kanady na rynkach Europy Zachodniej. Spowodowało to obniżenie cen zboża w Europie i zubożenie środkowo- i wschodnioeuropejskich rolników, już ubogich i zmagających się z przeludnieniem. „W ostatnich dekadach XIX wieku - pisze Adam Walaszek - około dwóch trzecich ludności wiejskiej zaborów austriackiego i pruskiego, a także jedna trzecia zaboru rosyjskiego zmuszone było poszukiwać zajęcia poza własną wsią" (Walaszek 2001: 13). Masowo wyjeżdżano w tym czasie do pracy w rolnictwie (Dania, Niemcy, Austria), przemyśle (Niemcy, Austria, Stany Zjednoczone, Kanada) oraz aby osiedlić się na stałe (Argentyna, Brazylia) (ibidem: 14).

W tym czasie w Brazylii, po zniesieniu niewolnictwa, potrzebna była duża liczba rąk do pracy przy plantacjach kawy oraz w modernizującym się rolnictwie na południu kraju. Rząd Brazylii (w dużej mierze, aby uspokoić nastroje wśród plantatorów kawy, którzy ponieśli znaczne straty) podpisał kontrakt z trzema prywatnymi firmami, które miały sprowadzić 750 tysięcy osób z Europy. Ponadto imigranci mieli „wybielič" i - w domyśle - zmodernizować ludność Brazylii, gdyż w 1890 roku na 14 milionów mieszkańców ok. 2 milionów stanowili czarnoskórzy (Mazurek 2006: 33-34).

Polscy chłopi napływali wraz z emigrantami z Niemiec i Włoch, nie zatrzymali się jednak w São Paulo na plantacjach kawy, ale kierowali się dalej na południe, gdzie otrzymywali ziemię i pracowali jako rolnicy (Listy... 2012; de Oliveira 2009; Kula 2012; Teleginski 2014: 93). Szacuje się, że na przełomie lat 80 i 90. XIX wieku z Królestwa Polskiego przypłynęło do Brazylii 40-80 tys. osób. W połowie lat 90. dołączyło do nich ok. 25 tys. osób z Galicji Wschodniej, a w latach 1910-1911 ok. 10 tys. emigrantów z Podlasia i Lubelszczyzny (Kula 2001: 118).

W moich badaniach skupiam się na jednej z głównych fal migracyjnych, mającej na celu kolonizację południowej części Brazylii i rozwój rolnictwa. Fala ta przypadła na lata 1890-1891 i w polskojęzycznej literaturze przedmiotu nazywana jest "gorączką brazylijską" (Kula 1972; Mazurek 2006). Używam określenia osadnictwo, mimo że autorzy brazylijscy (np. Batista Machado, Menasche, Salamoni 2015: 116-117) tę falę migracyjną z Europy do południowej Brazylii nazywają colonização (kolonizacja), a migrantów-rolników pochodzących z Europy - colonos (kolonizatorami). Określenia te są jednak w języku polskim wieloznaczne, zostaję więc przy polskim osadnictwie i osadnikach.

Historia polskiego, chłopskiego osadnictwa w Brazylii wiąże się z osobą Sebastiana Wosia (1844-1933), który w 1867 roku pod zmienionym nazwiskiem 
Edmund Saporski przybył do Brazylii z Siołkowic Starych koło Opola. Zamieszkał w stanie Santa Catarina, kolonizowanym wtedy przez Niemców. Dwa lata później sprowadził 16 rodzin z rodzinnej miejscowości do Brusque, do kolonii Sixteen Lots opuszczonej przez imigrantów irlandzkich. Rok później przybyło kolejnych 16 rodzin. Jednak trudne warunki klimatyczne, a także zatargi z miejscowymi Niemcami sprawiły, że Woś-Saporski wystarał się u władz sąsiedniej prowincji Parany - o ziemie dla swoich rodaków. W 1871 roku polscy osadnicy otrzymali ziemię w Pilarzinho koło Kurytyby (obecnie jest to część miasta). W ślad za nimi przybywali kolejni, którzy zasiedlali kolejne podkurytybskie wsie (Mazurek 2006: 56-57). Obecnie nadal w stanie Paraná mieszka najwięcej potomków Polaków, a Kurytyba jest uważana za stolicę brazylijskiej Polonii. Mniejsze skupiska Polonii znajdują się również w pozostałych południowych stanach: Santa Catarina i Rio Grande do Sul.

\section{Diaspora polska w Brazylii}

Polonia brazylijska jest znaczna, choć niezwykle trudna do policzenia, ponieważ pierwsi emigranci polskiego pochodzenia przyjeżdżali w czasie, gdy Polska nie istniała jako niepodległy kraj. Byli wówczas obywatelami Austrii, Prus i Rosji. Szacuje się jednak, że w Brazylii mieszka obecnie 800000 - 2000000 osób polskiego pochodzenia (Dvorak 2013).

Diaspora polska (podobnie zresztą, jak inne diaspory) jest bardzo zróżnicowana. Do niektórych krajów przyjeżdżali bowiem wykształceni Polacy, którzy zamieszkiwali miasta, do innych - ubodzy analfabeci, zasiedlający wsie. Jeszcze gdzie indziej - biedni i niewykształceni robotnicy, którzy zasilili lokalny proletariat, lub kobiety, które pracowały bądź pracują jako pomoce domowe. Z Polski, zwłaszcza w okresie wojen, wyjeżdżali również uchodźcy. Zresztą przez cały ten okres wyjeżdżali nie tylko Polacy, ale również przedstawiciele mniejszości narodowych. Nie tylko katolicy, ale i prawosławni, protestanci, żydzi czy ateiści. Trudno zatem mówić o jednej polskiej diasporze i jednej polskiej kulturze Polonii. Obecnie ponadto, w związku ze wzmożoną mobilnością, trudno niejednokrotnie ustalić, kto jest przedstawicielem diaspory, a kto wspólnoty transnarodowej czy innych ruchów migracyjnych, ponieważ jedni i drudzy mają większe możliwości podróżowania oraz utrzymywania wielowymiarowych kontaktów na odległość (zob. Faist 2010). Należy zatem pamiętać, że diaspory - zarówno pojęcie, jak i ludzie - są dynamiczne i podlegają ciągłym zmianom. Dotyczy to również diaspory polskiej: zarówno tej XIX-wiecznej, jak i współczesnych społeczności migranckich Polaków rozproszonych po świecie.

Mimo że Polonia brazylijska jest tak liczna, w Polsce nie jest dobrze znana. Nadal jest zbyt mało badań na ten temat, zwłaszcza jeśli chodzi o potomków Polaków 
mieszkających we wsiach brazylijskiego interioru. Bardzo duży wkład w poznanie Polonii brazylijskiej wnieśli i nadal wnoszą polscy i brazylijscy historycy, niemniej badań etnograficznych, bazujących na długotrwałym przebywaniu w terenie i prowadzeniu obserwacji, nie ma niemal wcale ${ }^{4}$. Moje badania są w zasadzie pierwszymi tego rodzaju badaniami ${ }^{5}$.

Przez wiele lat (w okresie wojen, a zwłaszcza po II wojnie światowej, gdy Polska znalazła się w orbicie wpływów Związku Radzieckiego), pomiędzy brazylijską Polonią a Polską nie było regularnych kontaktów. Brazylii nie zasilili również nowi migranci, jak to miało miejsce w Stanach Zjednoczonych czy w Kanadzie, został także zerwany kontakt pomiędzy jednostkami i wieloma rodzinami rozdzielonymi przez migrację (Walaszek 2001: 25). Dlatego również obecnie niewielu Brazylijczyków polskiego pochodzenia ma regularne kontakty z osobami z Polski. Od niedawna można jednak zaobserwować wzmożone zainteresowanie młodych ludzi studiami w Polsce (taką możliwość daje Konsulat Generalny RP w Kurytybie oraz Fundacja Dzieło Nowego Tysiąclecia - projekt „Nostra Polonia”6), wycieczkami turystycznymi do Polski czy staraniami o zdobycie polskiego paszportu. Regularny kontakt z polską kulturą, np. filmem czy muzyką, młodzi ludzie mają również dzięki mediom elektronicznym, a zwłaszcza uczestnictwu w sieciach społecznościowych, takich jak Facebook.

Specyfika tej fali migracyjnej Polaków do Brazylii wyraża się w kilku aspektach. Po pierwsze, fala migracyjna dotyczyła całych rodzin (np. w tym samym czasie do USA wyjeżdżali głównie młodzi mężczyźni, aby pracować w fabrykach; Mazurek 2006: 47). W Brazylii emigranci chcieli i mogli pozostać chłopami. Jest to szczególnie istotne, zwłaszcza, że w pamięci były jeszcze czasy przed uwłaszczeniem (1848 r. w zaborze pruskim, 1864 r. w Królestwie Kongresowym), kiedy to chłop pracował nie dla siebie, ale odrabiał tzw. pańszczyznę dla pana. W Brazylii otrzymywał ziemię na własność, więc de facto stawał się panem, co pokazuje lektura Listów emigrantów z USA i Brazylii (Listy... 2012).

Po drugie, polscy emigranci nie mieli żadnego wsparcia ze strony państwa wysyłającego (wszak byli poddanymi Rosji, Austrii lub Prus). Funkcję konsula starał się pełnić wspomniany Woś-Saporski, który był opiekunem Polaków, mierniczym, wytyczającym działki polskim imigrantom, ale także organizatorem życia społecznego i kulturalnego (Mazurek 2006: 58). Po trzecie, polscy imigranci z reguły byli niepiśmienni i jedynie w nielicznych domach zachowały się jakiekolwiek

${ }^{4}$ Zob. przegląd literatury polskojęzycznej na temat emigracji polskiej do Brazylii: Michalik-Sztumska 2010 oraz starsze, ale uwzględniające również pozycje obcojęzyczne: Kula 1972.

${ }^{5}$ Warto w tym miejscu wspomnieć nieduże badania etnograficzne Kingi Orzeł-Dereń, które zaowocowały publikacją 180-stronicowej monografii wsi Santana (ok. $80 \mathrm{~km}$ od mojego terenu badań), również zamieszkałej w większości przez potomków Polaków (Orzeł-Dereń 2011).

${ }^{6}$ http://buenosaires.msz.gov.pl/pl/c/MOBILE/aktualnosci/projekt_polonijny_nostra_polonia_realizowany_przez_fundacje_dzielo_nowego_tysiaclecia [data dostępu: 9.02.2017]. 
dokumenty osobiste migrantów. Jednak, mimo niesprzyjających okoliczności, jak negatywny stereotyp chłopa-Polaka czy prawo Getulio Vargasa z 1938 roku zakazujące używania języków etnicznych, w wielu wsiach zachowały się liczne elementy kultury polskiej. Trzeba dodać, że są to elementy kultury polskiej wsi (a dokładniej kultura lokalna konkretnych miejsc) w XIX wieku. Jest to również kultura konkretnej warstwy społecznej, mianowicie chłopów.

Brak wsparcia państwa wysyłającego oraz bieda i niepiśmienność spowodowały, że Polacy mieli niski status społeczny wśród emigrantów z Europy, niższy niż np. Włosi czy Niemcy. Stąd wziął się wspomniany negatywny stereotyp chłopa-Polaka i powstanie określeń takich, jak polaco burro czy polaco sem bandeira (Smolana 1979). Nadal zresztą wielu uważa, że określenie polaco (Polak, polski) jest obraźliwe, dlatego oficjalnie ${ }^{7}$ używa się słowa polonês. Wprawdzie wielu wybitnych Polaków w Brazylii zapracowało na to, aby ten negatywny stereotyp przezwyciężyć, jednak jednocześnie zapomina się lub milczy o wiejskim i rolniczym dziedzictwie polskiej diaspory w Brazylii. Chciałabym w moich badaniach oddać głos właśnie tym potomkom chłopów, którzy nadal żyją na wsi i zajmują się pracą na roli. Uważam, że ich codzienne praktyki, wartości i narracje są włączane w dyskurs związany z dziedzictwem Polonii o tyle, o ile wpisują się w homogeniczną wizję polskości: z jedną kulturą (tożsamością narodową, religią) dominującą. A tymczasem należy dodać, że Polonia brazylijska nie jest zupełnie jednolita, migranci pochodzili z różnych regionów (Wachowicz 1981) oraz często wywodzili się z mniejszości (narodowych, etnicznych, religijnych - zob. Mazurek 2006: 62). Nieśli więc ze sobą różne zwyczaje, dialekty, a także codzienne przyzwyczajenia jedzeniowe.

\section{Badania etnograficzne w polskiej wsi w Brazylii}

Od 2011 roku prowadzę etnograficzne badania terenowe w stanie Parana, głównie we wsi Rio Claro do Sul ${ }^{8}$. Jest to rozległa wieś (colonia) z kilkoma przysiółkami, zamieszkała głównie przez potomków Polaków oraz - w mniejszej części - Ukraińcó ${ }^{9}$, administracyjnie należąca do miasta Mallet. W terenie spędziłam łącznie ok. 3 miesiące, rozmawiając z ludźmi, biorąc udział w świętach, nabożeństwach, obchodząc pola $\mathrm{z}$ dumnymi gospodarzami i obserwując ich codzienną pracę, a także jadając $\mathrm{z}$ nimi i przygotowując posiłki. W czasie pobytu w terenie mieszkałam również $\mathrm{w}$ domu potomków Polaków. Przeprowadziłam ponad 30 wywiadów, ustrukturyzowanych i nieustrukturyzowanych, sporządziłam dziennik i notatki

\footnotetext{
7 W języku portugalskim, używanym w Portugalii, polski i Polak to Polaco, a Polka - Polaca.

${ }^{8}$ Badania w 2015 i 2016 roku zostały przeprowadzone dzięki stypendium podoktorskiemu „Fellow Mundus” realizowanemu na Uniwersytecie Federalnym Santa Catarina we Florianópolis.

${ }^{9}$ Zdaję sobie sprawę, że pod koniec XIX wieku nie używano określenia „Ukrainiec”, jednak obecnie jest to określenie emic samych mieszkańców Rio Claro i okolic.
} 


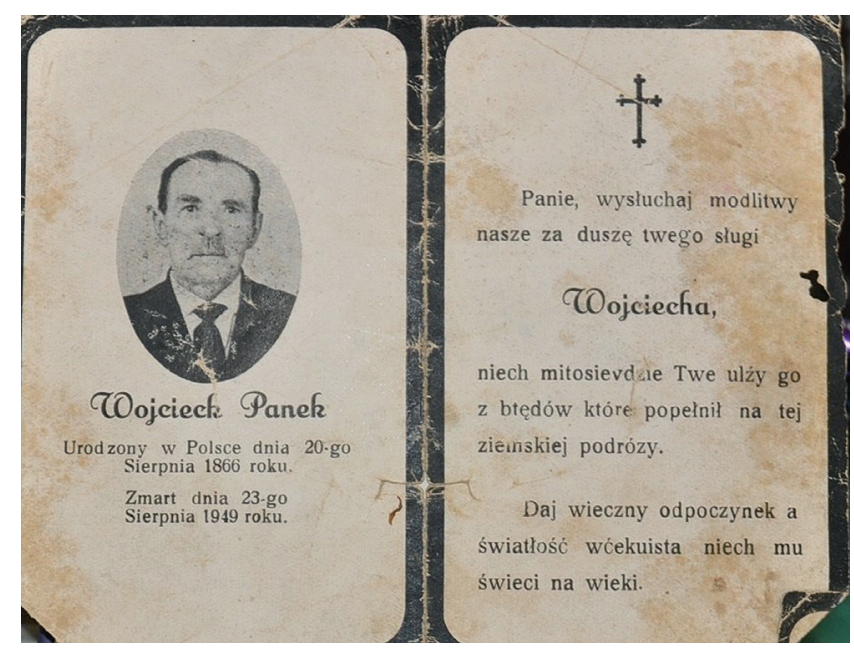

Fot. 1. Jeden z nielicznych zachowanych dokumentów osobistych

terenowe (ok. 40 stron komputeropisu), a także utworzyłam dokumentację fotograficzną i filmową. Rozmówców pozyskiwałam przede wszystkim popularną w etnografii metodą „kuli śnieżnej” (zob. Hammersley, Atkinson 1995).

Rio Claro zostało skolonizowane w 1891 przez imigrantów polskich pochodzących z różnych wsi Królestwa Kongresowego; sprowadzono wtedy 1400 rodzin i utworzono 1700 działek po 25 hektarów każda (Larocca, Larocca, de Almeida Lima 2008: 38 i 46). Nieco później, w 1896 r, przyjechali Polacy i Ukraińcy (Rusini) z Galicji Wschodniej.

Źródła historyczne podają, że Rio Claro na przełomie XIX i XX wieku było największą kolonią polską w stanie Paraná (Deina 1990: 36). Imigranci przyjechali w zasadzie ${ }^{10}$ do puszczy („Bodaj same bory były” - mówią moi rozmówcy), którą musieli wykarczować, zbudować domy i drogi. W następnej kolejności powstawał kościół i szkoła. Mieszkańcy Rio Claro w 1896 roku zbudowali duży drewniany kościół Matki Bożej Różańcowej, obecnie już nieistniejący, który nazywano „Częstochową Parańską", a także szkoły kilkuklasowe (od 1 do 4) w koloniach. W Rio Claro działało ponadto Towarzystwo Sportowe „Junak”, szkoła, biblioteki, kościół, a także mieszkały tam i pracowały siostry zakonne, które nauczały religii. W pobliskim Mallecie od 1911 do 1937 roku była również polska szkoła średnia im. Mikołaja Kopernika (Wachowicz 2002: 54).

Imigranci, którzy przyjechali pod koniec XIX wieku do stanu Paraná, w większości byli niepiśmiennymi chłopami. W nielicznych domach zachowały się dokumenty z tamtych czasów, np. książeczki do nabożeństwa, fotografie czy święte obrazy. Mieszkańcy w większości nie wiedzą, skąd pochodzili przodkowie; wiedzą jedynie,

${ }^{10}$ Mario Deina notuje, że na tym terenie mieszkało wcześniej „kilka rodzin” (Deina 1990: 23). 
że z Polski ${ }^{11}$ - taka informacja widnieje zresztą na zachowanych aktach ślubu, zgonu i urodzeń (fot. 1). Bardzo mało zachowało się również opowieści o podróży z Polski czy życiu tam przed emigracją. Jednym z powtarzających się wątków jest śmierć na statku i konieczność wyrzucenia ciała do morza bez możliwości pochowania go zgodnie ze zwyczajem - w ziemi. Innymi wątkami są wspomniana wyżej konieczność wyrębu lasu oraz strach przed nieznanymi dzikimi zwierzętami zamieszkującymi „bory”, a także opowieści o mroźnej zimie w Polsce („Bodaj tyle było śniegu, że trzeba było łopatą odgarniać").

Polacy, a potem także Ukraińcy, otrzymali od rządu brazylijskiego po ok. 25 ha (10 alqueires), które musieli odpracować, m.in. budując drogi. Otrzymali również ziarno na zasiew i zapas pożywienia na pierwsze miesiące pobytu w Brazylii (Listy... 2012). Później wielu gospodarzy dokupiło ziemię i rozbudowało swoje gospodarstwa.

Dzisiejsze Rio Claro to nadal wieś rolnicza. Składa się z centralnej wsi Rio Claro oraz pięciu przysiółków (colonias), numerowanych od 1 do 5 . W kolonii 5 mieszkają przede wszystkim potomkowie Ukraińców, w pozostałych - Polaków. Sama wieś Rio Claro jest mieszana, jednak ze znaczną przewagą potomków Polaków.

Do wsi wiedzie droga ziemna, z Malletu to blisko godzina samochodem, mimo że jest to niespełna 30 kilometrów. Domy stoją w znacznej odległości od drogi, a gdy chce się do któregoś wejść, należy stanąć przed bramą i głośno zaklaskać. Na ten umówiony sygnał gospodarze wychodzą z domu i zapraszają do środka. Witają się po polsku: przed południem „dzień dobry”, a po południu „dobry wieczór”.

Domy w Rio Claro są niskie, parterowe, w większości drewniane, kolorowe zazwyczaj niebieskie lub zielone. Strome, spadziste dachy to spadek po przodkach, którzy tak budowali, aby chronić dachy przed śniegiem (fot. 2). Gdy odwiedzałam moich rozmówców, niemal zawsze obchodziliśmy pola oraz oglądaliśmy gospodarstwo. Oto, co zanotowałam z jednej z takich wizyt $\mathrm{w}$ dzienniku terenowym:

Po obiedzie (pierogi, makaron, churrasco, ziemniaki, ryż, fiżon, oliwki i ciasto pieczone przez panią M.) idziemy z panem N. i chłopakami [jego nastoletnimi synami] ogląać pole. Teraz jest czas zbierania fumy [tytoniu]. Pan N. mówi, że jak ktoś się nie akustumuje [przyzwyczai], to bardzo głowa boli i spać nie można. Oni mają jeszcze pole fumy, bo to się dobrze sprzedaje, ale powoli ograniczają. Nie uprawiają popularnej w okolicy soi, bo też jest niebezpieczna. Dużo tych wenenów [pestycydów, trucizn] dawaja, potem od tego choroby jakieś moga być. Mają za to krzewy herby [erva-mate], która się dobrze sprzedaje i bory [las]. Drzewa sadzą eukaliptusowe, bo szybko rosną i już po kilku latach można ścinać. Oglądaliśmy też zagrodę dla świń oraz różne narzędzia gospodarskie. W pajorze [szopa] zachowały

${ }^{11}$ W Listach emigrantów Witolda Kuli, Marcina Kuli i Niny Asorodobaj-Kuli określenie Polska odnosi się do Królestwa Polskiego (Listy... 2012: 47). Jak wynika jednak z dokumentacji historycznej, w Rio Claro i okolicy osiedlali się również Polacy z zaboru austriackiego, a wielu z nich także mówi, że ich przodkowie przyjechali z Polski; niektórzy używają określenia „Austria”. 




Fot. 2. Krajobraz Rio Claro

się jeszcze stare rydle, kopaczki i żarna do mielenia kukurydzy na kaszę (notatki terenowe, 23.07.2016).

W Rio Claro nadal na co dzień praktykowane jest „bycie Polakiem”, co - w ślad za moimi interlokutorami - rozumiem jako używanie na co dzień języka polskiego, praktykowanie religii katolickiej i obchodzenie świąt (np. opisany niżej popularny zwyczaj „święconki”) oraz kultywowanie zwyczajów jedzeniowych.

Mieszkańcy Rio Claro w większości mówią po polsku i w tym języku zazwyczaj prowadziłam rozmowy i wywiady. Należy pamiętać, że jest to dialekt pochodzący z końca XIX wieku, z silnymi wpływami z języka portugalskiego, zwłaszcza w warstwie leksykalnej. W niektórych sytuacjach przechodziliśmy na język portugalski. Komunikacja pisemna, w tym np. na portalach społecznościowych, odbywa się w zasadzie tylko po portugalsku. Język polski, mimo że przekazywany z pokolenia $\mathrm{z}$ pokolenie, zachował się bowiem niemal jedynie w wersji mówionej. Mało osób czyta po polsku, jeszcze mniej pisze. Wiąże się to z luką w nauczaniu języka polskiego spowodowaną przez wprowadzenie w 1938 roku zakazu posługiwania się innymi językami niż portugalski w przestrzeni publicznej. Zamknięte zostały szkoły, a w tych, które zostały, zatrudniono nauczycieli portugalskojęzycznych. Ta tzw. polityka nacjonalizacyjna Getulio Vargasa trwała do połowy lat 80., a w wielu miejscowościach, zwłaszcza w miastach, dochodziło nawet do prześladowań osób mówiących w języku innym niż portugalski (Jussara Luporimi 2012; Wachowicz 
1970; Kula 2001: 122). Obecnie wiele osób wstydzi się mówić po polsku, mając świadomość tego, że jest to dialekt, a nie polszczyzna literacka (nieakuratny, misturado [pomieszany]). Od niedawna w wielu ośrodkach, w których mieszkają potomkowie Polaków, nauczany jest język polski ${ }^{12}$. Oczywiście, jest to jednak język ogólnopolski, a nie miejscowy dialekt. Ostatecznie, dla większości moich rozmówców językiem pierwszym jest kod mieszany (mixed code), łączący różne języki, dialekty, odmiany i rejestry, którymi użytkownicy posługują się tak, aby osiągnąć zamierzony efekt komunikacyjny (Blommaert 2013: 3).

\section{Pierogi na co dzień i od święta}

Brazylijska antropolożka Ellen Woortmann wprowadziła rozróżnienie na jedzenie typowe (comida típica) i jedzenie tradycyjne (comida tradicional). Jedzenie typowe jest zdaniem tej badaczki naznaczone przez egzotyzację i związane ze spojrzeniem z zewnątrz. Jedzenie tradycyjne natomiast wyraża wzorce i wartości tradycyjne danej grupy (Woortmann 2007: 111). Co istotne, jedzenie tradycyjne się zmienia i ulega ciągłym adaptacjom i przekształceniom (Woortmann 2007: 194). Inna brazylijska antropolożka, Maria Eunice Maciel (2004), pisze z kolei o cozinha emblemática, czyli „kuchni emblematycznej”. Znaczenie tego terminu częściowo pokrywa się z comida típica, ale nacisk położony jest na poczucie przynależności (pertencimento) i tożsamość. Maciel jako przykład podaje brazylijską feijoadę, danie różniące się od codziennego ryżu $\mathrm{z}$ fasolą i niepodawane na co dzień, a jednak prezentowane na zewnątrz jako danie narodowe czy element brazylijskiej tożsamości (Maciel 2004: 33). Wydaje się, że pierogi można opisać za pomocą trzech zaprezentowanych wyżej pojęć: jest to danie zarówno typowe, jak i tradycyjne, a także „emblematyczne”. Oznacza to, że pierogi są uważane za danie charakterystyczne dla polskiej kuchni (típica), i to zarówno przez samych potomków Polaków, jak i przez inne osoby, za danie stanowiące element lokalnej tradycji oraz za danie będące jednym z wyznaczników (emblematów) ich tożsamości.

W Paranie wiedza, czym są pierogi, a także barszcz, gołąbki, placki ziemniaczane czy bigos, jest powszechna. I wiadomo, że są to dania polskie, ewentualnie polskie i ukraińskie. Niemal na wszystkich festiwalach, w restauracjach etnicznych podawana jest comida típica. Brazylijczycy polskiego pochodzenia chętnie również fotografują typowo polskie potrawy podczas przyjęć u siebie w domu i zamieszczają zdjęcia na portalach społecznościowych. Pod postami z takimi fotografiami pojawiają się komentarze dotyczące tego, w jaki sposób dana osoba te potrawy przyrządza lub snute są nostalgiczne opowieści o „kuchni babci”.

${ }^{12} \mathrm{Na}$ przykład w miejscowości São Mateus do Sul zajęcia prowadzone były w ramach projektu „Tradição em Movimento” (2015-2017). Projekt finansował brazylijski koncern naftowy Petrobras. 


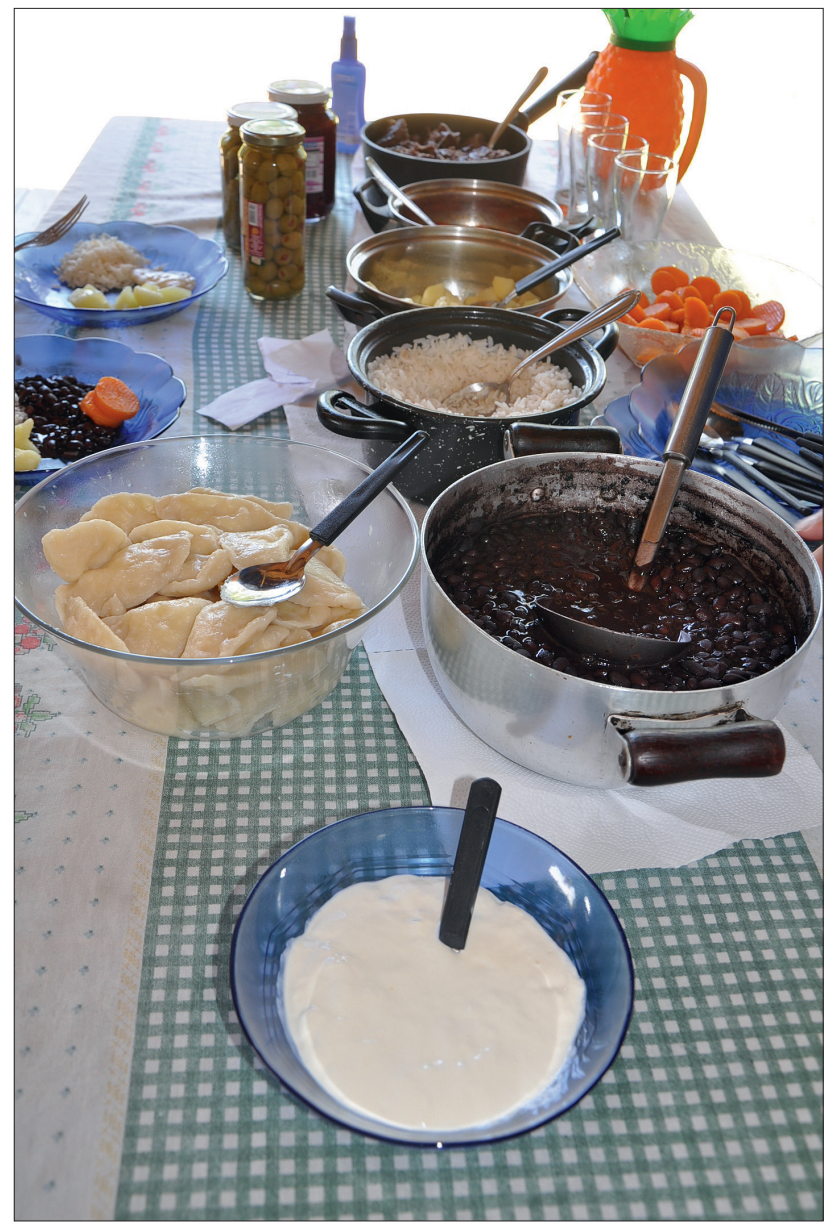

Fot. 3. Niedzielny obiad - ryż z fiżonem i pierogi

Internauci również wymieniają się informacjami, jak przyrządzić jakieś potrawy czy jak ich nazwę prawidłowo wymówić (problemem są np. gołąbki), a także, gdzie kupić konkretne - trudno dostępne w Brazylii - produkty, np. chrzan.

Podczas festiwali i świąt etnicznych potrawy są częścią programu kulturowego prezentowanego przez Brazylijczyków polskiego pochodzenia zarówno dla własnej społeczności, jak i na zewnątrz. Na przykład podczas Festa de Pierogi w miejscowości Araucaria koło Kurytyby w programie znajdują się: uroczysta parada ulicami miasteczka, występy grup folklorystycznych (nie tylko polskich, ale również ukraińskich i niemieckich), obiad z typowymi potrawami w menu oraz wieczorna impreza taneczna ${ }^{13}$.

${ }^{13}$ http://wesolydom.blogspot.com/2014/05/14-festa-do-pierogi.html [data dostępu: 25.02.2017]. 


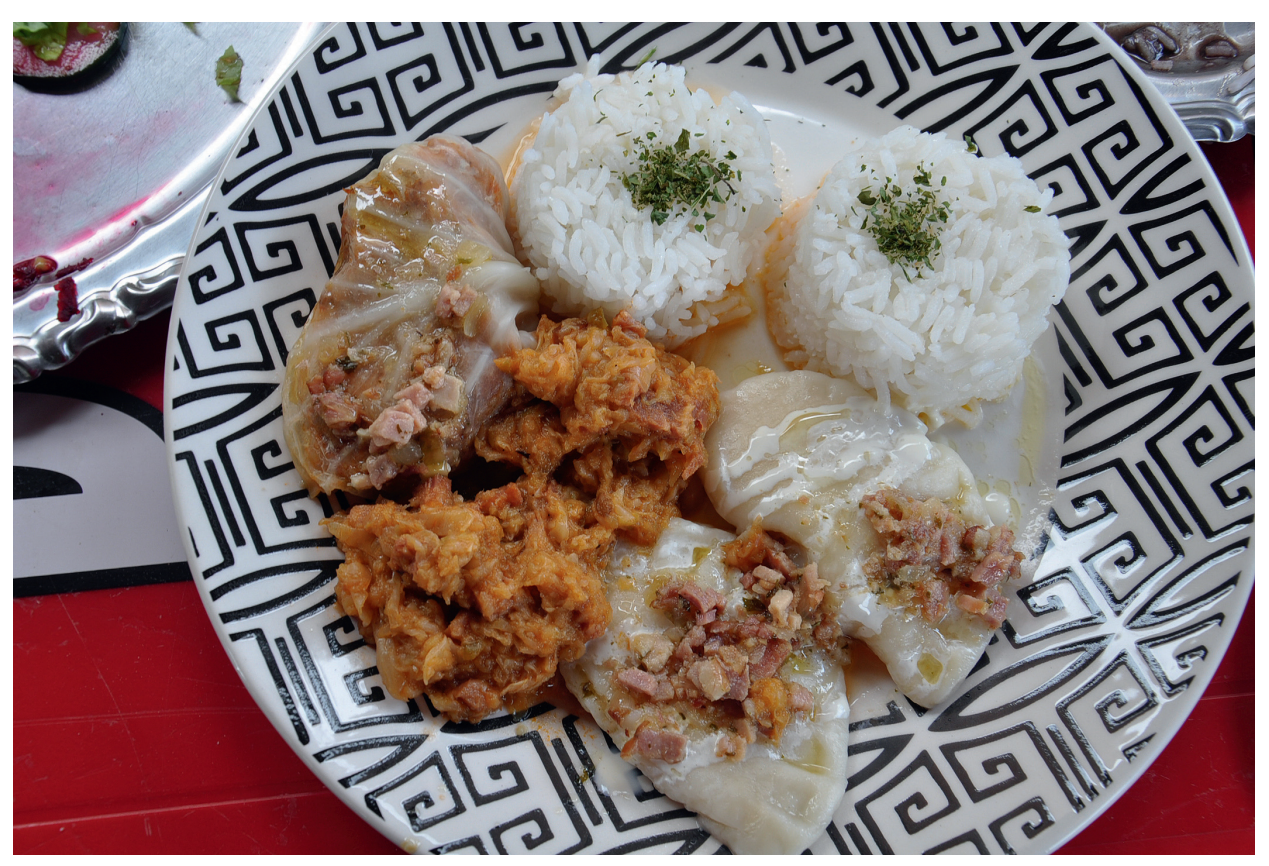

Fot. 4. Pierogi, bigos, gołąbki - polskie „dania typowe” w Kawiarni Krakowiak w Kurytybie

Potrawy uważne w Brazylii za polskie są - co oczywiste - nieco inne niż w samej Polsce, gdzie przecież również występują różnice regionalne. W Brazylii wiele potraw ulega adaptacji do lokalnych warunków i przyzwyczajeń smakowych. Najbardziej powszechne w Brazylii pierogi to pierogi z białym serem i ziemniakami. Te $\mathrm{z}$ reguły pojawiają się $\mathrm{w}$ domach, ale również na festiwalach i w restauracjach. Takie też jadałam, gdy byłam zapraszana do domów na niedzielny obiad (fot. 3 ). Niektóre osoby robią pierogi z kiszoną (lub konserwową) kapustą, ale także z czarną fasolą, zwaną tu fiżonem. Od jednej z rozmówczyń nauczyłam się robić wspaniałe pierogi z kapustą kiszoną i białym serem. Niezależnie od tego, jak zrobione i podane, pierogi nazywane są typowo polskimi (Teleginski 2014: 103) czy - mówiąc za Elishą P. Renne - są „ideologicznie podobne” do dań z miejsca pochodzenia, mimo że sposób produkcji jest odmienny (Renne 2007: 616). Można zapytać, dlaczego pierogi z mąki maniokowej, a nie pszennej, nadziewane fiżonem, nie są nazywane daniami typowo brazylijskimi? Przecież powstały w Brazylii i są przyrządzane przez Brazylijczyków. I są inne niż te znane obecnie w Polsce. Comida típica brasileira, czyli typowe jedzenie brazylijskie, to elementy kuchni indiańskiej, portugalskiej i afrykańskiej (przywiezionej wraz z niewolnikami, por. Fajans 2012). Nie należą do niej potrawy kuchni potomków emigrantów europejskich, tak charakterystycznej dla południa Brazylii, jak choćby polskie (słowiańskie) pierogi. Dlatego w kurytybskiej kawiarni „Krakowiak” podawane są dwa menu: „typowe polskie” (fot. 4) - 
z pierogami, bigosem, gołąbkami i buraczkami oraz „typowo brazylijskie” - z ryżem, fasolą, mięsem i surówką warzywną ${ }^{14}$.

Wiele potraw uznanych za typowo polskie nie jest jadanych na co dzień. To jedzenie od święta - na festiwale, na niedzielę lub inne okazje. Zróżnicowanie jedzenia na codzienne i niedzielne nie jest charakterystyczne tylko dla potomków Polaków, ale wydaje się uniwersalne i związane z podziałem czasu na powszedni i świąteczny. Niedzielne dania są nie tylko uznane za lepsze, pożywniejsze, bogatsze czy smaczniejsze, ale również zwykle ich przygotowanie zabiera więcej czasu (zob. Grim Thies, Thum 2015: 191, Domański, Karpiński, Przybysz, Straczuk 2015: 70-71). Jo umie robić pierogi - mówi rozmówczyni (K45, Mallet, 21.07.2016) ${ }^{15}$ - ale nima casu. Bo jo $w$ sobote robię aż do południa. Tyn starszy chłopok to pierze mi szmaty, to łone pomogaja mi. Ale nieroz jak do casu, to jo zrobie pierogi, bo jo lubie tyz. Pani ta zazwyczaj robi pierogi z białym serem, ale czasem również z fiżonem bądź - co mom, to tam wsadze ${ }^{16}$.

Na co dzień jada się to, co uważane jest za typowe jedzenie brazylijskie: ryż z czarną fasolą, czyli fiżonem, stanowi bazę do innych potraw. Ta baza zresztą pojawia się także w potrawach świątecznych. Jedna z moich rozmówczyni tak opisała potrawy wigilijne: Zawsze musi być tuzin jeścióch: ryż, fiżon, kapusta, sałata... co badź. Wtedy jest lato, wszystkiego jest pełno. No, mięsa ni ma. U nos się nie jadło mięsa (K 39, Mallet, 23.07.2016).

Pierogi stały się częścią kuchni świątecznej, są przekazywane z pokolenia na pokolenie w przestrzeni domowej, ale także za pośrednictwem festiwali czy restauracji. Powiązane są one $\mathrm{z}$ „pamięcią gastronomiczną” (memoria gastronomica) (Woortmann 2007: 183) o imigracyjnej przeszłości i wspomnieniami związanymi ze starszymi członkami rodziny (kobietami: matką, babką) (Teleginski 2014: 89) oraz są swego rodzaju „znacznikami tożsamości” (marcadores identitários) (Menasche 2005) lub emblematami (Maciel 2004) przynależności narodowej, etnicznej, czy też - jak argumentuję dalej - wiejskiej i lokalnej. Jak zauważa historyczka Neli Teleginski, trudno znaleźć je w wykazie dań nauczanych na kursach gotowania, ponieważ „wszyscy wiedzą, jak je przyrządzić” (Teleginski 2014: 94). Są jednocześnie na tyle popularne i tanie, że bez kłopotu można je kupić w formie mrożonek w każdym większym parańskim supermarkecie (fot. 5). Produkowane są przez rozmaite prywatne firmy, mają różne rodzaje nadzienia i są różnie nazywane: pierogi, pierogui, pirogui, pirogue (Filipack 2002: 283). Pierogi stały się ważnym produktem nie tylko etnicznej kuchni polskiej, ale również regionalnej kuchni regionu Paraná (Teleginski 2014).

Mimo kultywowania tradycji kulinarnych, potomkowie Polaków, żyjąc w otoczeniu osób odmiennych etnicznie i narodowo, przejęli od nich zwyczaje jedze-

${ }^{14}$ Zob. np. https://www.facebook.com/pg/nsdialisisckideabreu/about/ [data dostępu: 2.02.2017].

15 Schemat zapisu wywiadów: płeć, wiek, miejsce i data przeprowadzenia wywiadu.

16 Transkrypcja cytatów z wywiadów nie jest transkrypcją dialektologiczną, ale uproszczonym zapisem usłyszanych wypowiedzi. 


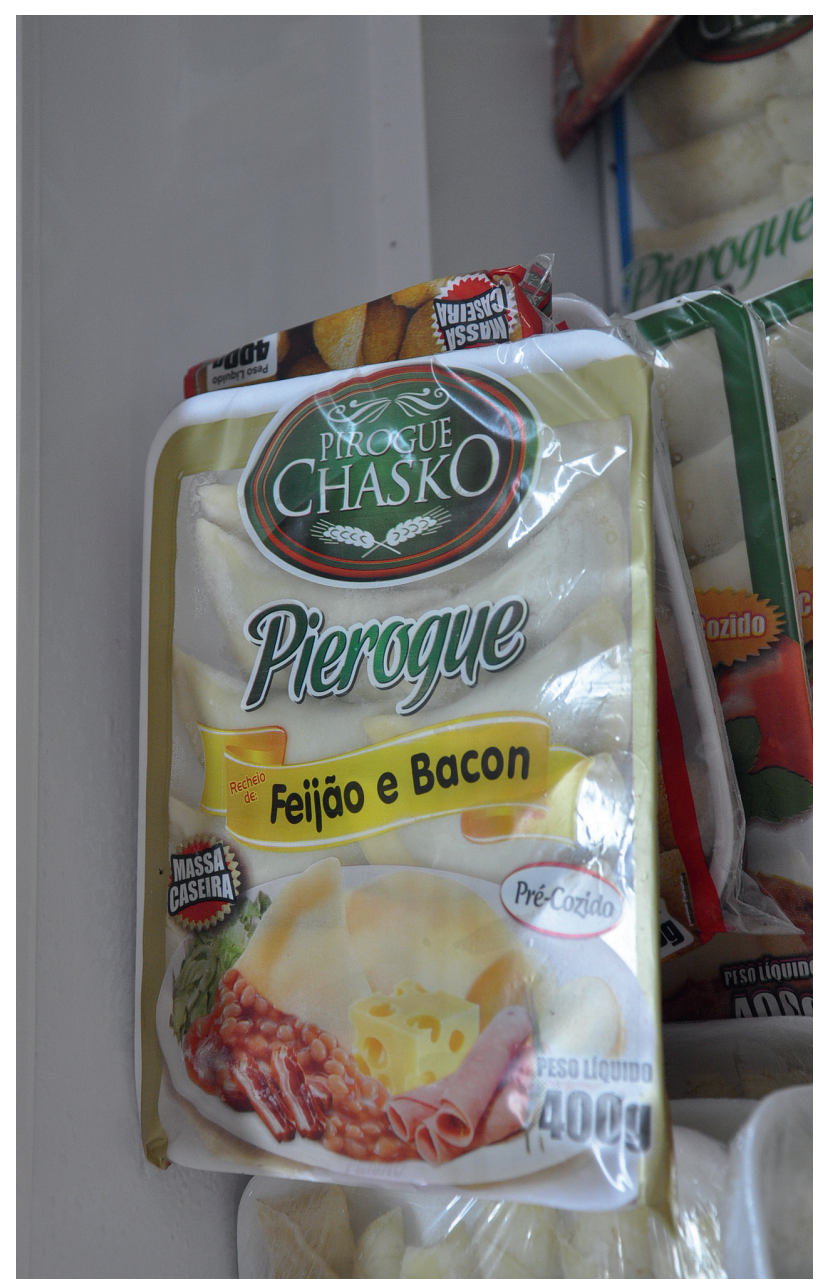

fot. 5. Mrożone pierogi z supermarketu

niowe. Jednym z przykładów jest chimarrão, którą jeden z moich rozmówców nazwał "polskim ojczenaszem” wyjaśniając, że od tego zaczyna się dzień. Chimarrão jest napojem przygotowywanym $z$ liści erva mate (ostrokrzew paragwajski), podawanym w tykwie (cuia) i pitym przez rurkę z filtrem (bomba). Brazylijczycy polskiego pochodzenia nie tylko piją chimarrão, ale także od pokoleń z powodzeniem uprawiają mate (nazywaną przez nich herba) oraz robią napar z gałązek krzewu mate, który nazywają herbatą. Ponieważ niemal od początku kolonizacji polskiej w Brazylii uprawiano kukurydzę, zwaną tu mileja (port. milho), wśród potomków Polaków popularna jest również polenta / mamałyga. Dawniej, gdy nie uprawiano jeszcze ryżu, z kukurydzy robiono kaszę. Obecnie kasza $z$ milei jest ważnym składnikiem paszy dla świń. 
Należy również pamiętać o dynamice zmian, związanej z nowymi upodobaniami smakowymi oraz globalnymi przemianami w gospodarstwach rolnych i stopniową utratą suwerenności żywieniowej rolników w związku z wprowadzeniem monokultur (Phillips 2006; Macnaghten, Carro-Ripalda 2016). Widoczne są one w mikroskali również na badanym przeze mnie terenie. Gdy byłam w Rio Claro na przełomie 2011 i 2012 roku $^{17}$, zadziwiły mnie samowystarczalne gospodarstwa, w których uprawiano w zasadzie wszystko, co potrzebne było do konsumpcji, w tym ryż, fasolę, kukurydzę, ziemniaki, cebulę, pszenicę oraz warzywa ogrodowe.

Moi rozmówcy pamiętają również grykę, żyto, len i chmiel. Z tego ostatniego jeszcze gdzieniegdzie wyrabia się piwo domowe (podpiwek), hoduje się także drożdże. Obecnie, po zaledwie pięciu latach, w krajobrazie wsi dominują monokultury genetycznie modyfikowanej soi oraz tytoniu (zob. Joensen, Semino, Paul 2005). Uprawiane są one na sprzedaż, a wiele produktów pochodzących wcześniej $\mathrm{z}$ własnej ziemi jest kupowanych. Kupowane są również gotowe produkty, takie jak chleb czy masło.

\section{Poza tożsamość narodową i etniczną}

Kim jest Polak w Brazylii? Czy jest to Brazylijczyk polskiego pochodzenia, Polak, Brazylijczyk, przedstawiciel Polonii czy może - Polono-Brazylijczyk (Kula 2012)?

Moi rozmówcy mówią o sobie, że są Polakami. Mimo że z Polski (a dokładniej z ziem polskich pod zaborami) wyjechali nie oni, lecz ich przodkowie, i to wiele dziesiątek lat temu. Wielu z nich wyjechało zresztą z terenów pogranicza (Galicji Wschodniej). Czym zatem jest przywieziona i reprodukowana przez nich kultura, którą określają mianem polskiej? Za przykład odpowiedzi na to pytanie niech posłuży wypowiedź rozmówcy, którego dwie córki wyszły za mąż za potomków Ukraińców (Rusinów). Mężczyzna ten pokazywał mi film z wesela starszej córki i opowiadał o przebiegu uroczystości:

Dawniej całą noc było baile [tańce]. Teroz to ino do meia-noite [północy], jak porżną to bolo [ciasto], I ten korowaj zrobią...

- A korowaj to Ukraińcy robią? A Polacy nie?

Polaki też teroz, tudo misturou. [wszystko się pomieszało] (M65, Rio Claro do Sul, 23.07.2016)

Z kolei inna osoba przyznaje, że korowaj to zwyczaj ukraiński:

Kutia i to tyn korowaj, co na weselach, to Ukraińcy. Moja mama zawsze mówiła, że to não é cultura polonesa [nie jest to polska kultura] (K 62, Rio Claro do Sul, 23.07.2016).

${ }_{17}$ Przeprowadziłam wtedy badania pilotażowe wśród przedstawicieli Polonii w Rio Claro, Mallecie oraz w miejscowości Dom Feliciano w stanie Rio Grande do Sul. 
Inna rozmówczyni deklaruje się jako Polka, mimo że wychowała się w pewnej mierze w kulturze ukraińskiej (jej starsza siostra, która po śmierci matki się nią opiekowała, wyszła za mąż za Ukraińca, a wieś, w której mieszkali, Rio Azul, również po części była zamieszkała przez Ukraińców). Uważa się ona za Polkę i jest obecnie szafarką komunii świętej w kościele, w którym posługuje ksiądz z Polski:

- Tam szkoła była, i była cerkwia, aha, miałam primeira comunião [pierwszą komunię]...

- To Pani primeira comuniao była w ukraińskiej cerkwi?

- W ukraińskij.(...)

- (...) A teraz to Pani chodzi do katolickiego kościoła?

- Sim, sim, ale te ukraińskie to też katolickie, tylko outro rito [inny ryt] (K, 71, Mallet, 22.12. 2015).

Rozmówczyni ta jednak mówi, że jest Polką, mimo że zanurzona jest we wspólną polsko-ukraińską czy nawet polsko-ukraińsko-brazylijską kulturę. Perspektywa narodowa, etniczna, a także wykluczające i homogeniczne pojęcie diaspory, nie pozwala jej być jednocześnie i Polką, i Ukrainką, choć pozwala - przynajmniej w teorii - na bycie Brazylijką. Jest bowiem obywatelką Brazylii, mówi po portugalsku („brazylijsku”). Jednak w praktyce tak się nie określa. Brazylijczycy to inni, nie-Polacy i nie-Ukraińcy (zob. Batista Machado, Menasche, Salamoni 2015: 127). Dlatego cytowana wyżej rozmówczyni wymienia osobno Polaków, Ukraińców i Brazylianów. To osoby albo $\mathrm{z}$ nieznanym pochodzeniem albo będące $\mathrm{z}$ innego regionu i/lub mające inny kolor skóry. Oto wypowiedź innej rozmówczyni na pytanie, czy jej dzieci mówią po polsku:

- Córka to jeszcze umi, ale wnuki to już nie, bo ona z Brazylianem ożeniona.

- A tu mieszkają?

- Nie, w Minas Gerais.

- To tam nie ma Polaków, co?

- Ni ma, same Brazyliany, czorne (K, 86, Rio Claro do Sul, 19.12. 2015).

Bycie Brazylijczykiem czy Brazylijką, podobnie jak określenie potrawy mianem „brazylijskiej”, nie zakłada pochodzenia imigranckiego. Mimo że Brazylia, a wraz z nią szeroko rozumiana kultura brazylijska, bazuje przecież na różnorodności kulturowej, narodowej i rasowej. Ale tak jak pierogi nie są zaliczane do potraw brazylijskich, tak i imigranckie południe Brazylii nie jest tym, które - stereotypowo - prezentowane jest na zewnątrz jako uosobienie „brazylijskości”. Innymi słowy, na południu Brazylii zwyczajowo nie tańczy się samby i nie ma znanego na cały świat karnawału, a większość mieszkańców ma jasny kolor skóry. Marcin Kula (2001: 128) pisze, że polskość w Brazylii jest rozumiana bardzo tradycyjnie, poprzez religię katolicką i folklor, ponieważ jest to migracja chłopska. Ja sądzę jednak, że kultura diaspory polskiej w Brazylii jest prezentowana na zewnątrz z jednej strony jako kultura wykształconych mężczyzn z miasta (np. twórca nowoczesnego teatru 
brazylijskiego Zbigniew Ziembiński, rzeźbiarz João Zaco Paraná (Jan Żak) - nie ma tu kobiet ani rolników, ani przedstawicieli mniejszości narodowych), a z drugiej poprzez folklor, ale w jego w romantyczno-inteligenckiej, estetycznej i malowniczej odsłonie.

Folklor, który prezentowany jest w Brazylii przez potomków Polaków, jest kolorowy i romantyczny. Festiwalom polonijnym towarzyszy muzyka, barwne stroje i „typowe” jedzenie. Gdy przyjrzeć się bliżej, i muzyka, i stroje, i jedzenie pochodzą z różnych regionów Polski i oczywiście nigdy nie były elementem codziennej kultury chłopów. Są to raczej elementy wiejskiej kultury świątecznej, przefiltrowanej przez wyobrażenia i konstrukcje pewnego wyobrażenia o Polsce i polskości ludowej, i jednocześnie o polskim ludzie. Chyba dobrym przykładem takiego folkloru i folkloryzacji, a wręcz samofolkloryzacji (Klekot 2014), jest zwyczaj święconki w Kurytybie. Uroczystość ta odbywa się w Bosque do Papa, parku imienia Jana Pawła II, gdzie mieści się miniskansen eksponujący elementy kultury materialnej polskich imigrantów. Co roku w Wielką Sobotę zbierają się tam miejscowi Brazylijczycy polskiego pochodzenia, zespoły folklorystyczne, polscy księża, ale także wszyscy inni zainteresowani. Jest to bowiem istotne wydarzenie na skalę miasta, przyciągające nawet kilka tysięcy osób. W centrum parku, na dużym stole, ustawiane są przyniesione przez ludzi kosze z kolorowo pomalowanymi jajkami, z mięsem, chlebem i słodkimi ciastami. Samemu aktowi święcenia pokarmów towarzyszą występy muzyczne i taneczne, a całość przypomina brazylijską festę. Przy okazji święcenia pokarmów, podawane są „typowo polskie dania”, odbywają się warsztaty malowania pisanek, a także udostępniany jest do zwiedzania skansen.

Jednocześnie we wsiach parańskiego interioru w Wielką Sobotę przynoszone są do rzymskokatolickich kościołów i greckokatolickich cerkwi kosze z jedzeniem, które zostają poświęcone przez kapłana, a następnie zabrane przez wiernych do domów. Święceniu nie towarzyszą ani występy folklorystyczne, ani warsztaty. Zwyczaj malowania jajek i przynoszenia do kościołów święconki przekazywany jest z pokolenia na pokolenie. Podobnie jak tradycja przygotowywania i spożywania pierogów rozprzestrzenił się on na niepolskich i nieukraińskich mieszkańców regionu.

\section{Pierogi a sprawa polonijna}

W studiach nad pojęciem diaspory, a także w dyskursie publicznym i potocznym, wielu autorów bierze za pewnik związek pojęcia diaspory z tożsamością narodową / etniczną / religijną (Walaszek 2001). A tymczasem wiele działań jest pewną wypadkową kultury kraju pochodzenia i kultury kraju przyjmującego. A nawet więcej - kultury regionu, wsi pochodzenia i kultury regionu czy wsi kraju przyjmującego. Ponadto, pewne elementy kultury, w tym codzienne zwyczaje jedzeniowe, przekraczają granice regionów i państw i raczej świadczą o pochodzeniu 
badanych osób z obszaru o podobnych warunkach geograficznych bądź wiążą się z podobnym sposobem gospodarowania. Trzeba pamiętać, że Polacy przybyli do Brazylii w końcu XIX wieku z ubogich wsi, wielu z nich było niepiśmiennych i mało mobilnych. Wyjazd na drugi kontynent był często jedyną podróżą poza własną okolicę, pozostającą w zasięgu wyprawy pieszej. Mówienie o ich praktykach, że są „polskie”, jest dużym nadużyciem. One są lokalne: silnie związane z obszarem, z którego migranci pochodzili. Innymi słowy, nigdy w całej Polsce nie jadło się takich samych pierogów. Jednocześnie również całkiem podobne pierogi jadali i jadają np. Polacy, Ukraińcy czy Litwini.

Jedna z fal migracyjnych do Rio Claro do Sul to Polacy i Ukraińcy. Przybywali oni razem $\mathrm{z}$ terenów, które obecnie leżą w granicach Polski lub w granicach Ukrainy; wtedy była to część zaboru austriackiego. Różnił ich dialekt, a przede wszystkim religia (Ukraińcy byli i są grekokatolikami, Polacy - katolikami obrządku rzymskiego). Choć, jak mówi cytowana wyżej rozmówczyni, nawet tu istotnej różnicy nie ma, bo to tylko outro rito. W tradycji kulinarnej tej różnicy nie ma. Pierogi jedzą i Ukraińcy, i Polacy, różnice są w szczegółach i nazwie (pierogi, perohe); jedni i drudzy mają barszcz i gołąbki. I jedni, i drudzy uważają to za część swojego dziedzictwa jedzeniowego (Geyzen 2014). Oczywiście, i jedni, i drudzy mają do tego prawo. Pierogi znajdują się w centrum tożsamości diaspory polskiej, dlatego tak podatne są na patrymonializację. To samo dotyczy pierogów jako potrawy potomków Ukraińców. Co więcej, wśród brazylijskich Polaków jada się również potrawy znane jako typowe wśród przedstawicieli innych grup narodowych migrantów z Europy. Dla przykładu wspomnę swoje spotkanie z Pomeranos (emigrantami z Pomorza Zachodniego, posługującymi się językiem pomerano, bliskim niemieckiemu, a obecnie znajdującemu się w stadium kodyfikacji). Spotkanie odbyło się w okolicy Pelotas, w stanie Rio Grande do Sul. Zaoferowano mi na obiad potrawę, którą przedstawiono jako „typowo pomorską" (prato tipico pomerano). A było to nic innego jak „nasze” placki ziemniaczane, tu nazywane Rievelsback. Jest to oczywiście dziedzictwo wspólne i Polaków, i mieszkańców Pomorza Zachodniego, i wynika ono z podobnych doświadczeń i trybu życia przed emigracją. Chociaż, na co zwracają uwagę Michael di Giovine i Ronda L. Brulotte, jedzenie „jest potężnym narzędziem artykułowania i negocjowania tożsamości jednostkowych i zbiorowych" (2014: 89), a wręcz - jak pisał Claude Fishler (1988: 275) - „jedzenie jest zasadnicze dla naszego poczucia tożsamości”. Dotyczy to oczywiście również rozmaitych form tożsamości lokalnej. Dlatego zapewne rację mają badacze brazylijscy, którzy wychodzą poza optykę narodową i etniczną i piszą o „wspólnej tożsamości wiejskiej” (compartilhada identidade colona) (Batista Machado, Menasche, Salamoni 2015), pokazując, że odzwierciedla ona również codzienne praktyki jedzeniowe. Innymi słowy, jak mówiła moja rozmówczyni: $E$, tu to wszystkie maja jedzenie to samo: ryż z fiżonem, czy Polok, czy Ukrainiec, Brazylian, jednakowo (K 44, Rio Claro do Sul, 20.07.2016). 


\section{Zakończenie}

Etnografka pytająca o polskie jedzenie w Brazylii dostanie szybką odpowiedź, a na pierwszym miejscu pojawią się pierogi. Łatwo też dowie się, gdzie w Kurytybie można pierogi zjeść albo od kogo je kupić. Trudno wyobrazić sobie festiwal kultury polskiej w Brazylii bez pierogów i polskiej muzyki. Dlaczego pierogi jadają też Ukraińcy i również oni uważają, że jest to ich comida típica? Wreszcie: czym jest polskość w Brazylii i jak to jest "być Polakiem" w południowej Brazylii? To ostatnie pytanie wymaga dalszych, pogłębionych badań.

W badaniach diaspory nie jest łatwo wyjść poza optykę narodową i etniczną, ponieważ sami potomkowie imigrantów stosują kategorie etniczne i narodowe. Jako Polacy, Ukraińcy, Niemcy czy Włosi przedstawiani są również w literaturze przedmiotu i dyskursie publicznym. Jako tacy mają wszak nie tylko jasną identyfikację, ale również wsparcie konsulatu i instytucji publicznych z kraju przodków. Niemniej, jak próbowałam udowodnić w niniejszym tekście, kultura Brazylijczyków polskiego pochodzenia jest silnie zlokalizowana - zarówno w miejscu, z którego pochodzili ich przodkowie, jak i w miejscu, do której przybyli. Codzienne praktyki jedzeniowe pokazują, jak istotne są wiejskie i chłopskie, tj. rolnicze i związane z konkretną warstwą społeczną, korzenie tej migracji. Dlatego tak podobne do siebie są pewne potrawy uważane przez Brazylijczyków polskiego pochodzenia za typowo (típica) polskie i ukraińskie, a przez potomków migrantów z Pomorza Zachodniego (Pomeranos) za pomorskie. Jedni i drudzy jadali je bowiem przed emigracją i jest to ich „bagaż wniesiony”.

Jednocześnie, ze względu na perspektywę etniczną i narodową, a także patrymonializację praktyk potomków migrantów (Geyzen 2014), produkty i potrawy stają się emblematami (Maciel 2014) danych grup. Jako tzw. comida típica, razem z wybranymi elementami folkloru, stają się częścią programu kulturowego prezentowanego zarówno dla własnej społeczności, jak i na zewnątrz. Jednocześnie, jak to ma miejsce w przypadku pierogów, sposób ich przygotowania nadal przekazywany jest z pokolenia na pokolenie i postrzegany przez Brazylijczyków polskiego (i ukraińskiego) pochodzenia jako część tradycji (comida tradicional). Dzięki temu, że są one łatwe do przygotowania, można je bez trudu adaptować do lokalnych warunków i przyzwyczajeń. Potomkowie Polaków ponadto chętnie przyswajają nowe smaki i sposoby przyrządzania potraw. Świadczą o tym nie tylko pierogi z fiżonem, których spożywanie można interpretować jako swoiste konsumowanie zarówno (elementów) polskości, jak i (elementów) brazylijskości, ale również popularność yerba-mate czy potraw na bazie ryżu i kukurydzy.

Określenie pierogi oznacza różne produkty, różnie wyglądające i rozmaicie smakujące: jedne podawane są na słodko, inne na słono, jedne na obiad, inne na kolację lub deser. I mimo że podlegają ciągłym zmianom i adaptacjom, pierogi, nawet te z mąki maniokowej i z fiżonem, są uważane za potrawę "typowo polską". 


\section{Bibliografia}

Abbots E. (2016), Approaches to Food and Migration: Rootedness, Being and Belonging, w: Klein J., Watson J. (red.), The Handbook of Food and Anthropology, London: Bloomsbury, s. $115-132$.

Batista Machado C. J., Menasche R., Salamoni G. (2015), Comida, identidade e simbolismo: saberes e práticas alimentares na conformação da italianidade na colônia de Pelotas, w: Menasche R. (red.), Saberes e Sabores da Colônia. Alimentação e cultura como abordagem para o estudo do rural, Porto Alegre: Editora da UFRGS, s. 115-132.

Bauböck R., Faist T. (red.) (2010), Diaspora and Transnationalism: Concepts, Theories and Methods, Amsterdam: IMISCOE-Amsterdam University Press.

Bielenin-Lenczowska K. (2018), Spaghetti with ajvar: An ethnography of migration, gender, learning and change, w: Mata-Codesal D., Abranches M. (red.), Food Parcels in International Migration: Intimate Connections, Palgrave Macmillan, s. 117-139.

Blommaert J. (2014), Language and the study of diversity, w: Vertovec S. (red.), Handbook of Diversity Studies, Routledge.

Brulotte R. L., De Giovine M. A. (2014), Introduction. Food and Foodways as Cultural Heritage, w: Brulotte R. L., De Giovine M. A. (red.), Edible Identitites. Food as Cultural Heritage, Farnham: Ashgate, s. 1-27.

Ćwierczakiewiczowa L. (1871), 365 obiadów za 5 złotych, przez Lucynę C., autorkę Jedynych i praktycznych przepisów. $Z$ dodatkiem 120 obiadów postnych bez ryb, Warszawa: Drukarnia Aleksandra Pajewskiego.

Diner H. R. (2001), Hungering for America: Italian, Iris of migration, Cambridge: Harvard University Press.

Domański H., Karpiński Z., Przybysz D., Straczuk J. (2015), Wzory jedzenia a struktura społeczna, Warszawa: Wydawnictwo Naukowe Scholar.

Dvorak A. K. (2013), A Hidden Immigration: The Geography of Polish-Brazilian Cultural Identity, Ph.D. thesis, University of California, Los Angeles.

Fajans J. (2012), Brazilian Food. Race, Class and Identity in Regional Cuisines, London: Bloomsbury.

Filipack F. (2002), Dicionário sociolinguístico paranaense, Curitiba: Imprensa Oficial.

Fishler C. (1988), Food, self and identity, “Social Science Information”, vol. 27, no. 2, s. 275-292.

Gazeta... (1938), Gazeta Polska w Brazylii, nr 33, s. 9.

Geyzen A. (2014), Food Studies and the Heritage Turn: a Conceptual Repertoire, "Food and History", vol. 12, no 2, s. 67-96.

Grim Thies V., Thum C. (2015), Sabores da colônia: a alimentação como estratégia da memória, w: Menasche R. (red.), Saberes e Sabores da Colônia. Alimentação e cultura como abordagem para o estudo do rural, Porto Alegre: Editora da UFRGS, s. 189-200.

Hammersley M., Atkinson P. (1995), Metody badań terenowych, Poznań: Wydawnictwo Zysk i S-ka.

Jussara Luporimi T. (2012), Educação polonesa: os fundamentos da educação escolar étnica revisitados, IX Seminário nacional de estudos e pesquisas "História, sociedade e educação no Brasil”, Universidade Federal da Paraíba - João Pessoa - 3107- 03/08/2012, http://www.histedbr.fe.unicamp.br/acer_histedbr/seminario/seminario9/PDFs/2.64.pdf [data dostępu: 2.02.2017]. 
Kelly T. M. (2001), 'Honoring Helga. The Little Lefse Maker': Regional Food as Social Marker, Tradition, and Art, w: Inness S. A. (red.), Cooking Lessons. The Politics of Gender and Food, Lanham, Boulder, New York and Oxford: Rowman and Littlefield, s. 19-39.

Kershen A. J. (red.) (2002), Food in the Migrant Experience, Aldershot: Ashgate.

Klekot E. (2014), Samofolkloryzacja: współczesna sztuka ludowa z perspektywy krytyki postkolonialnej, „Kultura współczesna”, nr 1 „Autarkia kultur peryferyjnych”, s. 86-99.

Kozinets R. (2012), Netnografia. Badania etnograficzne on-line, przeł. M. Brzozowska-Brywczyńska, Warszawa: Wydawnictwo Naukowe PWN.

Kozioł A. (2003), Polski słownik kuchenny i biesiadny, Kraków: Oficyna Wydawnicza TEXT.

Kula M. (1972), Polska literatura dotycząca Ameryki Łacińskiej XIX i XX w., „Dzieje najnowsze", rocznik IV, nr 2, s. 119-136.

Kula M. (2001), Polska diaspora w Brazylii, w: Walaszek A. (red.), Polska diaspora, Kraków: Wydawnictwo Literackie, s. 118-129.

Kula M. (2012), Polono-Brazylijczycy i parę kwestii im bliskich, Warszawa: Biblioteka Iberyjska.

Larocca J. J., Larocca P. L., de Almeida Lima C. (2008), Casa Eslavo Paranaense. Arquitetura de madeira dos colonos poloneses e ucrainianos do sul do Paraná, Ponta Grossa: Larocca Associados S/S Ltda.

Leksykon... (2012), Zieliński K. et al. (red.), Leksykon Podkarpackich smaków, Rzeszów: Urząd Marszałkowski Województwa Podkarpackiego.

Listy... (2012), Listy emigrantów z Brazylii i Stanów Zjednoczonych 1890-1891, do druku podali, wstępem opatrzyli Kula W., Assorodobaj-Kula N., Kula M., Warszawa: Muzeum Historii Ruchu Ludowego.

Maciel M. E. (2001), Cultura e alimentação ou o que tem a ver os macaquinhos de Koshima com Brillat-Savarin?, "Horizontes Antropológicos", Porto Alegre, vol. 7, nr 16, s. 145-156.

Maciel M. E. (2004), Uma cozinha à brasileira, "Estudos Históricos”, nr 33, s. 25-39.

Macnaghten P., Carro-Ripalda S. (2016), Governing Agricultural Sustainability Global lessons from GM crops, Routledge.

Mata-Codesal D., Abranches M. (red.) (2018), Food Parcels in International Migration: Intimate Connections, Palgrave Macmillan.

Mazurek J. (2006), Kraj a emigracja: ruch ludowy wobec wychodźstwa chłopskiego do krajów Ameryki Łacińskiej (do 1939 roku), Warszawa: Muzeum Historii Polskiego Ruchu Ludowego.

Menasche R. (2005), Comida: alimento transformado pela cultura (Entrevista), "IHU On-Line", São Leopoldo, s. 8-12.

Michalik-Sztumska M. (2010), Wychodźstwo polskie w Brazylii. Stan badań nad zagadnieniem, „Prace Naukowe Akademii im. Jana Długosza w Częstochowie”, seria: Zeszyty Historyczne XI, s. 323-330.

Mintz S. W. (2008), Food and Diaspora, „Food, Culture and Society”, vol. 11, no. 4, s. 510-523.

Ochorowicz-Monatowa M. (1913), Uniwersalna książka kucharska z ilustracyami i kolorowemi tablicami odznaczona na wystawie hygienicznej w Warszawie w 1910 r.: przeszło 2200 skromnych $i$ wytwornych przepisów gospodarskich i kuchennych $z$ uwzględnieniem niezbędnych warunków odpowiedniej dyety codziennej hygieny oraz kuchni jarskiej, Warszawa i Lwów: E. Wende i S-ka.

Phillips L. (2006), Food and Globalization, "Annual Review of Anthropology", nr 35, s. 37-57.

Poulain J. P. (2013), Sociologias da Alimentação: os comedores e oespaço social alimentar, Florianopolis: Editora da UFSC. 
Renne E. P. (2007), Mass Producing Food Traditions for West Africans Abroad, "American Anthropologist", vol. 109, no. 4, s. 616-625.

Smith R. (2003), Diasporic Memberships in Historical Perspective: Comparative Insights from the Mexican, Italian and Polish Cases, “The International Migration Review”, vol. 37, no. 3 “Transnational Migration: International Perspectives”, s. 724-759.

Smolana K. (1979), Sobre a gênese do estereótipo do Polonês na América Latina (caso brasileiro), "Estudos latinoamericanos", nr 5, s. 69-80.

Teleginski N. (2014), Recheio de memórias: o pierogi e a identitade polonesa no Paraná, Brasil, "Revista Geonordeste", vol. XXV, nr 2, s. 87-106.

Wachowicz R. (1970), As escolas da colonização polonesa no Brasil, "Anais de Cominidade Brasileira-Polonesa”, nr 2, Curitiba: Comunidade Brasileira-Polonesa, s. 13-110.

Wachowicz R. (2002), História do Paraná. Curitiba: Imprensa Oficial.

Wachowicz R. C. (1981), O camponês polonês no Brasil, Curitiba: Fundação Cultural, Casa Romário Martins.

Walaszek A. (2001), Polska diaspora, w: Walaszek A. (red.), Polska diaspora, Kraków: Wydawnictwo Literackie, s. 7-29.

Wandel M. et al. (2008), Changes in food habits after migration among South Asians settled in Oslo: The effect of demographic, socio-economic and integration factors, "Appetite", nr 50, s. 376-385.

Woortmann E. (2007), Padrões tradicionais e modernizaçao: comida e trabalho entre campones teuto-brasileiros, w: Menasche R. (red.), A agricultura familiar a mesa, Porto Alegre: IEPE, s. 177-196. 